\title{
Expanded Contents List
}

List of Figures and Tables

Abbreviations

viii

xi

Preface and Acknowledgements xiv

Introduction

I. Thinking Politically: The Nature of Local Government in Scotland

Defining Characteristics of Scottish Local Government 5

The Legal Basis of Scottish Local Authorities $\quad 7$

The Purpose of Local Government in Scotland:

A Quasi-Constitutional View

The Purpose of Local Government in Scotland:

A Political Science View

Conclusion

2. Mapping the Networks and Relationships of Scottish Local Authorities

Relations with the Scottish Executive

Relations with Boards/Quangos/Agencies/NDPBs

Relations with Local Communities

Relations with the Scottish Parliament and Party Political Interests

Relations with Bodies Representing Local Authority Interests 
Relations with the Legal System and Associated Bodies 38

Conclusion $\quad 38$

3. Scottish Local Authority Structures: From Feudal Burghs to Single Tier Authorities

From Feudalism to Capitalism: Early Local Authority

Structures in Scotland

1966-75: Wheatley Reforms and the Advent of the Two Tier System

1991-6: The Creation of a Single Tier System

A Flawed Case for Change?

Single Tier Authorities, Conservative Style:

A Critique

Scottish Structures: Distinctiveness in the UK? 62

Conclusion

4. Council Decision-Making Structures: From Traditional Administration to Post-Devolution Modernisation

1950s-60s: The 'Traditional' Approach to Council

Decision-Making

1970s: The Corporate Approach in Scotland

1979-97: The Impact of the Conservatives:

Fragmentation and 'Depoliticisation'

Post-1996: Unitary Authorities and the Modernisation of Political Management Arrangements

Conclusion: Continuity rather than Discontinuity

5. Councillors, Elections and the Electoral System:

A Healthy Democratic Foundation?

The Multiple Roles of Councillors: Representative,

Politician and Manager

Elections and the Electoral System: Turnout, Voting Behaviour and FPTP v. PR

Conclusion - A Healthy Democratic Foundation?

6. Beyond Elections: Non-Electoral Forms of Public Participation and Non-Elected Local Governance

Non-Electoral Forms of Public Participation

The Growth of Non-Elected Local Governance

Conclusion - Beyond Elections: Contributing to a Healthy Local Democracy? 
7. Political Parties in Scottish Local Government $\quad 137$

Scottish Labour Party 138

Scottish National Party 141

Scottish Conservative and Unionist Party 142

Scottish Liberal Democrats $\quad 144$

Scottish Green Party and Scottish Socialist Party 146

Independents 147

Conclusion - A Scottish Distinctiveness in Party Trends? 148

8. Reconstructing Accountability: Value for Money and the Rise of the Performance Culture in Scottish

Councils 155

Background: The Old Regime of CCT 156

Best Value 161

The Rise of the Performance Culture in Scottish Local

Government 166

Conclusion - VFM as the 'New' Accountability 174

9. Financing Scottish Local Government 179

Local Government Finance in Scotland: An Overview 180

Revenue Finance: Sources, Restrictions and Issues 181

Capital Finance: Sources, Restrictions and Issues 197

Scotland's 32 Local Authorities: Free to Spend? 205

Conclusion 207

10. The Bigger Picture: Central-Local Relations, Multi-Level Governance and Globalisation 211

Central-Local Relations 211

Scottish Local Government and Multi-Level Governance 223

Globalisation and Scottish Local Government 227

Conclusion 230

Conclusion: Has Devolution Made a Difference to Local

Government in Scotland?

Bibliography 239

Index

266 